\title{
Impact of soil compaction on root development and yield of meadow-grass
}

\author{
T. Gtą \\ Institute of Machinery Exploitation, Ergonomics and Production Processes, University of Agriculture, Balicka 116B, \\ 31-149 Cracow, Poland
}

Received November 14, 2011; accepted December 30, 2011

A b stract. The field experiment was carried out on a smoothstalked meadow-grass to analyse the effect of tractor traffic on herbage production and root morphology. The multiple passes of tractor changed physical properties of soil. Increase in bulk density and penetration resistance of soil under smooth-stalked meadowgrass was recorded up to the depth of $30 \mathrm{~cm}$. The tractor traffic resulted in changes in smooth-stalked meadow-grass yields. During the second and the third harvest it was found that wheel traffic decreased plant yields. For the first harvest the opposite effect in herbage production was noticed. The tractor traffic significantly changed the root morphometric properties in the upper, $0-5 \mathrm{~cm}$, soil layer. Intensive tractor traffic (four and six passes) significantly increased the root length in diameter range of 0.1-0.5 mm. There were no differences in both mean root diameter and specific root length what indicated that traffic treatment applied did not change the root diameter. The results indicate that smooth-stalked meadow-grass could be recommended for compacted soils when intensive traffic is present.

K e y w o rd s: meadow-grass, soil compaction, yields, roots

\section{INTRODUCTION}

Modern agricultural production systems tend to increase the number of passes and the loads carried on agricultural vehicles, resulting in a potential for increased compaction. Soil compaction is now recognized as one of the main factors that can lower crop yields and thus is a serious agricultural problem. Compaction leads to soil structure degradation, where the size and shape of pores are changed (Hamza and Anderson, 2005). Many researchers agree that soil compaction leads to plant yield reduction (Whalley et al., 2008) including decreased production of perennial forage crops (Głąb, 2008). This yield decline is the consequence of both soil compaction and shoot injury caused by wheel traffic. It is a serious problem for perennial crops, where the soil is subjected to wheel traffic. Soil strength is increased year-after-year and all machine traffic during field operation cause direct damages to plants which are reported to be more important in contributing to decreased plant yield than soil compaction. On the other hand, it has also been reported that the yields of perennial plants were not always reduced by compaction and sometimes were larger in compacted soil than in non-compacted (Frost, 1998). These trends could be attributed to better water and nutrient supply and recovery of soil pore system (Scott et al., 2005).

The degraded soil physical environment due to compaction influences of shoots as well as roots growth and development. Soil compaction increases mechanical impedance, creates unfavourable growing conditions for roots and restricts oxygen, water and nutrients supply (Chen and Weil, 2010; Głąb and Kopeć, 2009). A common response of the root system to increasing bulk density is to decrease in length, concentrating roots in the upper layer and decreasing rooting depth (Lipiec et al., 2003). Strongly compacted soils are usually penetrated by roots in cracks, fissures and biopores (macropores formed by earthworms). This provides advantage to elongating roots but also results in a heterogeneous root distribution. However, changes in root system appearance do not necessarily cause an alteration in aboveground growth or yield (Kristoffersen and Riley, 2005). Overall, it is a very difficult to quantify con- sistently in field trials the relation between root growth and plant yield.

It was also stated that plant roots played favourable role in recovery of strongly compacted soil (Milleret et al., 2009). Author stated in previous work (Głąb, 2005) that roots of perennial legumes reduced soil compaction and improved water retention of soil. 
In Poland the total area of permanent grassland is over $4 \mathrm{mln}$ ha, which comprises $13 \%$ of the country area and $22 \%$ of all agricultural land. The area of permanent grassland meadows is over 2390 ha, which is nearly $75 \%$ of all permanent grasslands. There are usually two or three cut meadows. The most popular method of harvest conservation is hay production using the surface of the meadow (more than $60 \%$ of total herbage production) (Statistical Yearbook, 2008). Although the new silage technologies appeared (bales, tubes, etc.) hay making is still popular method of conserving grass in Central Europe mainly due to low expenses and favourable climate condition. However, one of the great disadvantages of this method is a very intensive tractor traffic connected with operation like cutting, tedding, raking, lifting and fertilizing.

The objective of this study was to evaluate the effect of:

- tractor traffic on soil physical properties,

- soil compaction on root morphology and

- tractor passes on herbage production of smooth-stalked meadow-grass.

\section{MATERIAL AND METHODS}

The smooth-stalked meadow-grass is a very common for extensive permanent grassland in Central Europe and plays important role as valuable botanical component in grass mixtures (Gajda, 1997).

This study was conducted as a field experiment located in Mydlniki near Cracow, Poland (5004'N, $19^{\circ} 51^{\prime} \mathrm{E}, 211 \mathrm{~m}$ a.s.1., slope: $2^{\circ}$ ) over a three-year period (2007-2009). The climate of the experimental site is temperate-continental. Average annual precipitation reaches $839 \mathrm{~mm}$ year $^{-1}$, mean daily temperature is around $6^{\circ} \mathrm{C}$. The field experiment was located on silty loam Mollic Fluvisol (IUSS Working Group WRB, 2007) with a $290 \mathrm{~g} \mathrm{~kg}^{-1}$ of sand, $670 \mathrm{~g} \mathrm{~kg}^{-1}$ of silt and $40 \mathrm{~g} \mathrm{~kg}^{-1}$ of clay.

The soil was ploughed and harrowed in spring 2006 for seedbed preparation then, in April 2006, the smooth-stalked meadow-grass (Poa pratensis L.) seeds were sown at a rate of $16 \mathrm{~kg} \mathrm{ha}^{-1}$. In 2006 herbicides and frequent cutting were applied due to removing weeds. Fertilization was applied every year at a rate of: $\mathrm{N}-100, \mathrm{P}_{2} \mathrm{O}_{5}-60$, and $\mathrm{K}_{2} \mathrm{O}-80 \mathrm{~kg} \mathrm{ha}^{-1}$. Experimental plots $\left(9 \mathrm{~m}^{2}\right)$ were established in a completely randomized design with four replications. Four compaction treatments were applied using the following numbers of tractor passes: untreated control (P0), two passes (P2), four passes (P4) and six passes (P6). URSUS C-360 tractor of $2056 \mathrm{~kg}$ mass was used for traffic simulation. The inflation pressure of the front tires (6.00-16 6PR) of tractor was $150 \mathrm{kPa}$ and that of rear tires (14.9-28 8PR) $100 \mathrm{kPa}$. The multiple passes were applied in a wheel-beside-wheel design, after every harvest ( 3 times a year). The wheel traffic was applied at soil moisture content of approximately $0.30 \pm 0.03 \mathrm{~cm}^{-3} \mathrm{~cm}^{-3}$. This water content corresponded to the value of a field water capacity. The harvest dates were: May 24, July 19, and September 13 in 2007; May 23, July 21, and September 15 in
2008; June 5, July 18, and September 12 in 2009. Dry matter production was determined on each plot based on grass herbage cut with an Agria mower (Typ 3200, Agria-Werke $\mathrm{GmbH}$, Germany). The dry matter (DM) of the yield was determined by drying a subsample of $500 \mathrm{~g}$ at $70^{\circ} \mathrm{C}$ to a constant mass.

The soil samples were collected in September 2007, 2008 and 2009, after the third harvest. Three soil layers: 0-5, 10-15 and 20-25 cm, were chosen for the investigation. Dry bulk density was measured by taking samples of soil using corer with a $100 \mathrm{~cm}^{3}$ volume sample ring in four replications for every plot. The samples were weighted and dried $\left(105^{\circ} \mathrm{C}\right)$ until they reached a constant mass. Total porosity was calculated from solid phase density $\left(2.56 \mathrm{~g} \mathrm{~cm}^{-3}\right)$ and dry bulk density of the samples. The penetration resistance was measured using STIBOKA penetrometer (Ejkelkamp Agrisearch Equipment, the Netherlands) with a base area of $1 \mathrm{~cm}^{2}$ and $60^{\circ}$ cone angle. The penetration measurements were done up to the depth of $70 \mathrm{~cm}$ in six replications for every plot.

Roots were sampled using the soil-core method in autumn 2009. The core diameter was $80 \mathrm{~mm}$. Samples were taken in four replication for every plot from a $15 \mathrm{~cm}$ depth and were divided into 3 sections: 0-5, 5-10 and 10-15 cm. Roots were washed using a hydropneumatic elutriation system (Smucker et al., 1982) to remove mineral particles from the samples. Before scanning, any organic contaminations were manually removed. Digital images were obtained with an Epson Perfection 4870 Photo (Seiko Epson Corp., Japan) scanner. The collected images were saved in the tiff format with a resolution of $600 \mathrm{dpi}$. Then the images were analyzed using APHELION, software for image analysis (ADCIS S.A. and Amerinex Applied Imaging, France) and root characteristics were calculated. The measured root length was divided into eight diameter classes: $0-0.02$, $0.02-0.05,0.05-0.1,0.1-0.2,0.2-0.5,0.5-1.0,1.0-2.0$ and $>2.0 \mathrm{~mm}$. The root length density (RLD) was calculated by dividing the total root length by the volume of the sample. The specific root length (SRL) was calculated by dividing the total root length by the root dry mass. The mean diameter (MD) was calculated as weighted mean of root length for particular diameter classes. After scanning, roots were dried at $70^{\circ} \mathrm{C}$ for dry matter determination (RDM).

An analysis of variance for a completely randomized design was performed to evaluate the significance of soil compaction on root characteristics and plant yields using the statistical package STATISTICA 6.0 (StatSoft Inc.). Means were compared using Tukey test with a level of significance of $\mathrm{p}<0.05$.

\section{RESULTS AND DISCUSSION}

The results in bulk density, total porosity and penetration resistance are given in Table 1. The tractor traffic applied significantly affected measured physical parameters of soil. The more intensive wheeling was applied the higher bulk density was recorded. The highest value of bulk density 
T a b I e 1. Physical properties of soil related to four compaction levels (P0, P2, P4 and P6)

\begin{tabular}{|c|c|c|c|c|c|c|c|c|c|}
\hline \multirow{2}{*}{ Treatment } & \multicolumn{3}{|c|}{ Bulk density $\left(\mathrm{g} \mathrm{cm}^{-3}\right)$} & \multicolumn{3}{|c|}{ Total porosity } & \multicolumn{3}{|c|}{ Penetration resistance $(\mathrm{MPa})$} \\
\hline & 2007 & 2008 & 2009 & 2007 & 2008 & 2009 & 2007 & 2008 & 2009 \\
\hline \multicolumn{10}{|c|}{ Soil depth $0-10 \mathrm{~cm}$} \\
\hline P0 & 1.44 & 1.42 & 1.42 & 0.44 & 0.45 & 0.45 & 1.52 & 2.02 & 2.13 \\
\hline $\mathrm{P} 2$ & 1.48 & 1.50 & 1.49 & 0.42 & 0.41 & 0.42 & 2.40 & 2.64 & 2.29 \\
\hline P4 & 1.57 & 1.54 & 1.51 & 0.39 & 0.40 & 0.41 & 2.71 & 2.78 & 2.35 \\
\hline P6 & 1.64 & 1.60 & 1.55 & 0.36 & 0.38 & 0.40 & 3.26 & 3.26 & 2.51 \\
\hline \multicolumn{10}{|c|}{ Soil depth $10-20 \mathrm{~cm}$} \\
\hline P0 & 1.46 & 1.43 & 1.43 & 0.43 & 0.44 & 0.44 & 1.44 & 1.69 & 2.51 \\
\hline $\mathrm{P} 2$ & 1.47 & 1.54 & 1.52 & 0.43 & 0.40 & 0.41 & 1.95 & 2.34 & 2.62 \\
\hline P4 & 1.52 & 1.58 & 1.55 & 0.41 & 0.38 & 0.40 & 2.41 & 2.41 & 2.57 \\
\hline P6 & 1.59 & 1.62 & 1.58 & 0.38 & 0.37 & 0.38 & 2.62 & 2.57 & 2.52 \\
\hline \multicolumn{10}{|c|}{ Soil depth $20-30 \mathrm{~cm}$} \\
\hline P0 & 1.47 & 1.45 & 1.46 & 0.43 & 0.43 & 0.43 & 1.34 & 1.59 & 2.18 \\
\hline P2 & 1.51 & 1.48 & 1.48 & 0.41 & 0.42 & 0.42 & 1.91 & 2.17 & 2.35 \\
\hline P4 & 1.53 & 1.50 & 1.51 & 0.40 & 0.41 & 0.41 & 2.34 & 2.25 & 2.39 \\
\hline P6 & 1.53 & 1.47 & 1.50 & 0.40 & 0.42 & 0.42 & 2.56 & 2.41 & 2.32 \\
\hline $\operatorname{LSD}_{0.05}$ & 0.042 & 0.036 & 0.038 & 0.017 & 0.016 & 0.017 & 0.321 & 0.330 & 0.312 \\
\hline
\end{tabular}

was recorded in the $0-10 \mathrm{~cm}$ soil layer at the $\mathrm{P} 6$ treatment in 2007. It was observed that in the next years, 2008 and 2009, the bulk density of soil at strongly compacted treatments (P4 and P6) decreased. The bulk density at the P0 treated control, did not statistically change during three years of the experiment ( $1.42 \mathrm{~g} \mathrm{~cm}^{-3}$ in average in $0-10 \mathrm{~cm}$ soil layer).

The opposite effect was recorded in the total porosity. The intensive tractor traffic resulted in decrease in total porosity. The lowest value was observed in 2007 at the P6 treatment ( 0.36 in the $0-10 \mathrm{~cm}$ soil layer). However, it increased in the next years and reached 0.40 in 2009.

The tractor traffic caused soil compaction what resulted in higher penetration resistance with respect to control untreated (P0). In September 2007, after the third harvest, the penetration resistance become stable on all treatments and did not change during the 2008 and 2009. It was also observed that penetration resistance slightly decreased during the experiment especially in strongly compacted soil (P6). The highest value of penetration resistance $(3.26 \mathrm{MPa})$ was noticed in the upper soil layer in the P6 treatment in 2007, whereas in 2009 at the same treatment this value decreased to $2.51 \mathrm{MPa}$.

The highest root concentration was found in the upper $(0-5 \mathrm{~cm})$ soil layer. There was approximately $81 \%$ of dry root matter (RDM) of the total, $0-15 \mathrm{~cm}$, investigated soil layer whereas in the 5-10 and $10-15 \mathrm{~cm}$, there were only $12 \%$ and $7 \%$, respectively (Fig. 1). The similar relationship was obtained for RLD values, where the participations of roots were 63,20 and $17 \%$ for the $0-5,5-10$ and $10-15 \mathrm{~cm}$ soil layers, respectively (Fig. 2).

The tractor traffic significantly changed the root morphometric properties. However, the changes were noticed only in the upper, 0-5 cm, soil layer. The P6 and P4 treatments significantly increased root length in diameter range of 0.1 $0.5 \mathrm{~mm}$ in comparison with the P0. The root length distribution in particular roots diameter classes is presented in Fig. 3. The highest RLD value, above $50 \mathrm{~cm} \mathrm{~cm}^{-3}$, was noticed at the P4 treatment. Whereas the RLD value at untreated control (P0) and the $\mathrm{P} 2$ treatment was below $40 \mathrm{~cm} \mathrm{~cm}^{-3}$. Below the depth of $5 \mathrm{~cm}$ the RLD was only $14 \mathrm{~cm} \mathrm{~cm}^{-3}$ in average. The similar effect was also noticed for the RDM parameter. Intensive wheel passes involved higher concentration of dry root matter $\left(0.011 \mathrm{~g} \mathrm{~cm}^{-3}\right.$ at the P6) in the $0-5 \mathrm{~cm}$ soil layer with respect to untreated control $\left(0.007 \mathrm{~g} \mathrm{~cm}^{-3}\right)$. The SRL was not altered by multiple passes and it varied from $6337 \mathrm{~cm} \mathrm{~g}^{-1}$ in the upper $(0-5 \mathrm{~cm})$ soil layer to above $12430 \mathrm{~cm} \mathrm{~g}^{-1}$ below $5 \mathrm{~cm}$ (Fig. 4). The mean value of the MD was $0.32 \mathrm{~mm}$ and it was also not affected by both, the soil depth and soil density caused by tractor traffic (Fig. 5). The lack of differences in the MD and SRL values indicated that traffic treatment applied did not change the root diameter.

The total annual yield of smooth-stalked meadow-grass was $8.1 \mathrm{t} \mathrm{DM} \mathrm{ha}^{-1}$ (Table 2). Three cuts were obtained every year and they were approximately 47,33 and $21 \%$ of total 


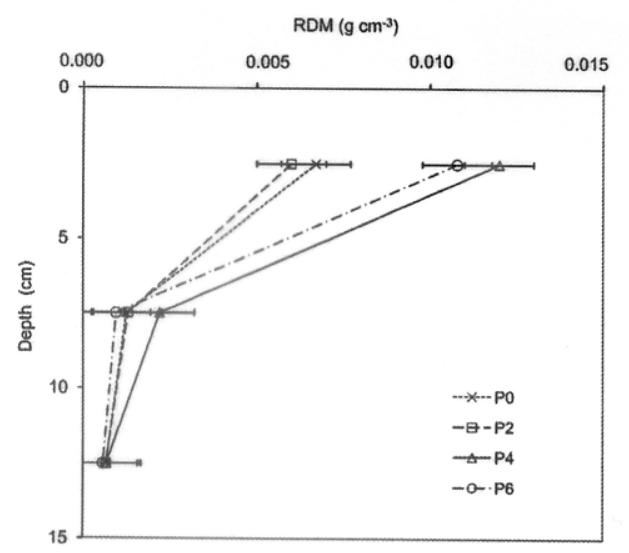

Fig. 1. The effect of tractor traffic on Poa pratensis L. root dry matter (RDM) distribution in three soil layers. Horizontal bars represent standard errors.

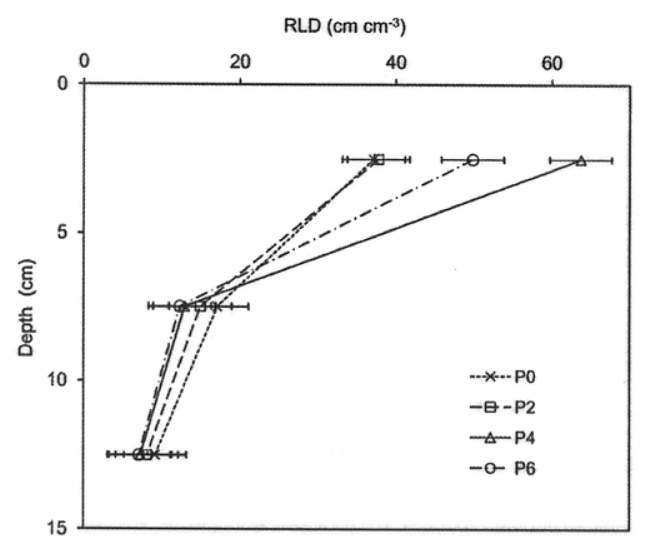

Fig. 2. The effect of tractor traffic on Poa pratensis L. root length density (RLD) distribution in three soil layers. Explanations as in Fig. 1 .
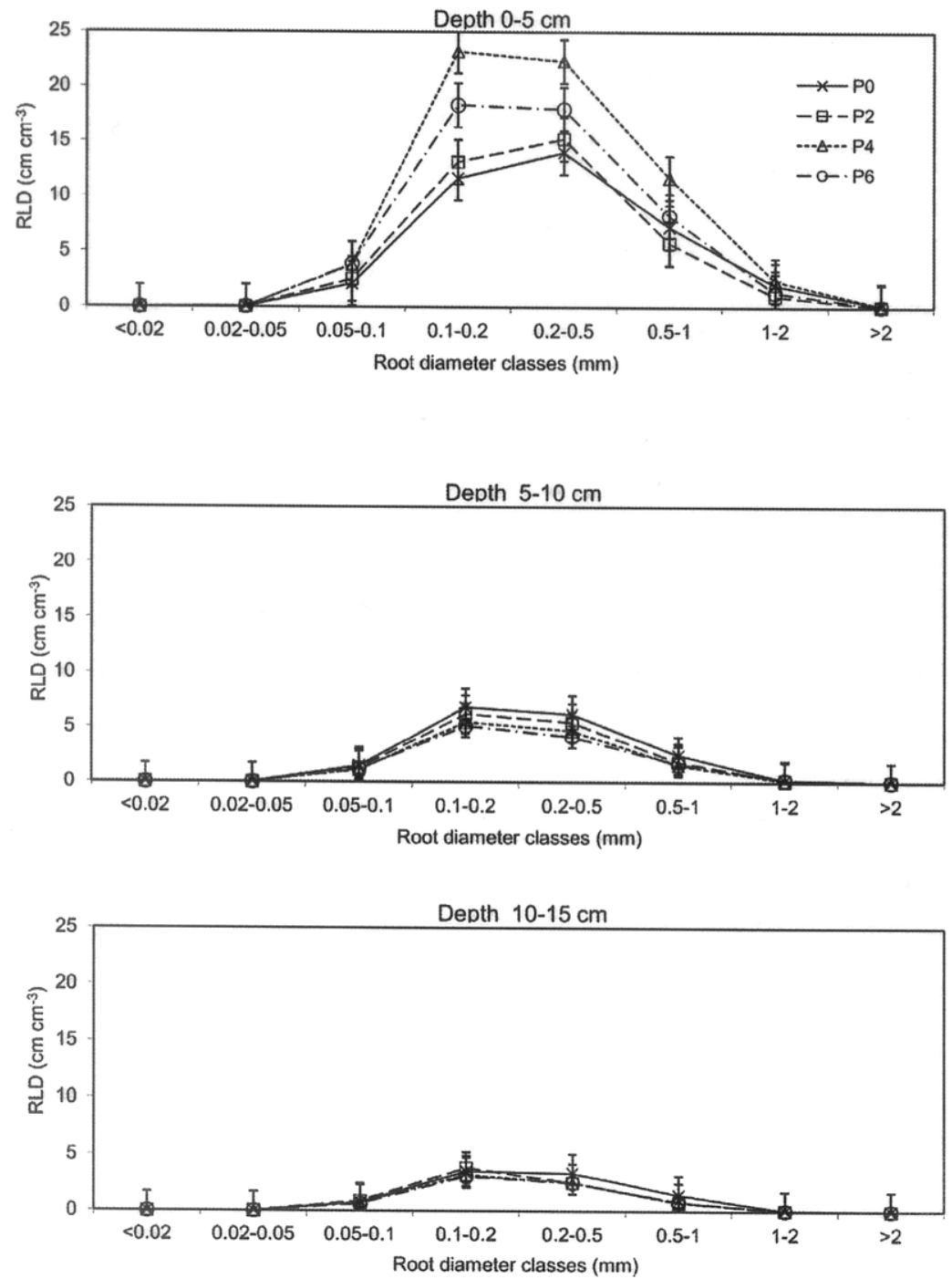

Fig. 3. The effect of tractor traffic on Poa pratensis L. root length density (RLD) distribution for different root diameter classes. Vertical bars represent standard errors. 


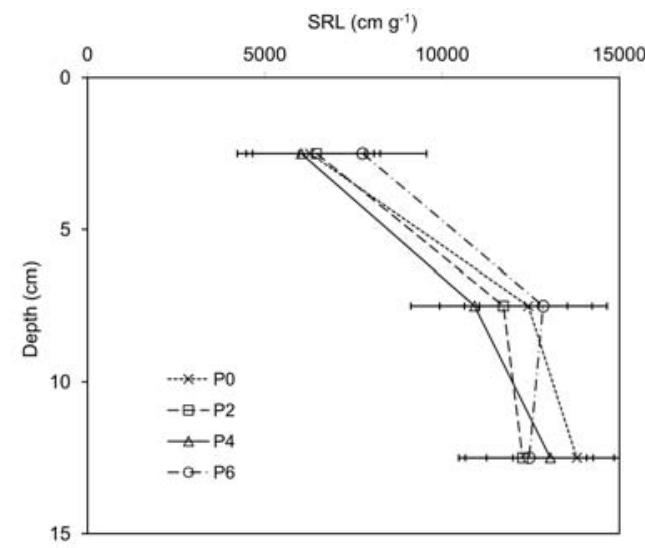

Fig. 4. The effect of tractor traffic on Poa pratensis L. specific root length (SRL) distribution in three soil layers. Horizontal bars represent standard errors.

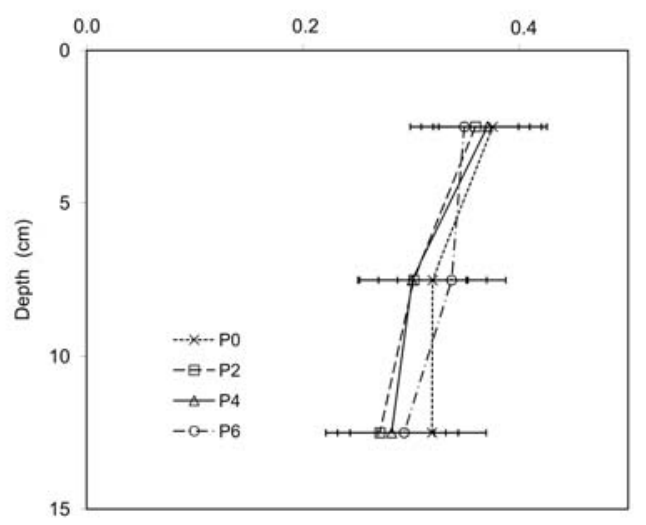

Fig. 5. The effect of tractor traffic on Poa pratensis L. root mean diameter (MD) distribution in three soil layers. Horizontal bars represent standard errors.

T a b l e 2. The effect of tractor traffic on Poa pratensis L. dry matter (DM) production in three years of experiment

\begin{tabular}{|c|c|c|c|c|c|c|c|c|c|}
\hline \multirow{3}{*}{ Treatment } & \multicolumn{9}{|c|}{ Yield (t DM ha $\left.{ }^{-1}\right)$} \\
\hline & \multicolumn{3}{|c|}{1 st cut } & \multicolumn{3}{|c|}{ 2nd cut } & \multicolumn{3}{|c|}{3 rd cut } \\
\hline & 2007 & 2008 & 2009 & 2007 & 2008 & 2009 & 2007 & 2008 & 2009 \\
\hline $\mathrm{P} 0$ & 3.59 & 3.24 & 4.05 & 2.89 & 2.85 & 3.13 & 1.70 & 2.51 & 1.91 \\
\hline $\mathrm{P} 2$ & 3.58 & 3.75 & 3.92 & 2.95 & 2.22 & 2.96 & 1.70 & 2.28 & 1.60 \\
\hline $\mathrm{P} 4$ & 3.59 & 3.63 & 4.46 & 2.75 & 2.02 & 2.87 & 1.62 & 2.33 & 1.28 \\
\hline P6 & 3.57 & 3.76 & 4.39 & 2.48 & 2.06 & 2.84 & 1.52 & 2.18 & 1.38 \\
\hline $\operatorname{LSD}_{0.05}$ & n.s. & 0.232 & 0.229 & 0.193 & 0.198 & 0.201 & 0.150 & 0.148 & 0.168 \\
\hline
\end{tabular}

annual yield. There was significant interaction between treatment applied and the time of harvest. In the first cut it was observed that increase in number of passes increased the herbage production. The only exception was the first cut in 2007 when no significant differences between treatments were observed because this harvest was done before the first tractor traffic. In both, 2008 and 2009, the tractor traffic significantly increased the DM values during the first cut.

For the second and the third cut it was found that multiple passes decreased plant yields. For the second cut the DM of the $\mathrm{P} 2$ treatment was $92 \%$ in average with respect to the P0. At the P4 and P6 treatments it was 86 and $83 \%$, respectively. This tendency for the third cut was very similar. In spite of this the total annual herbage production were not affected by traffic treatment applied. The yield decrease noticed during the second and third cuts was compensated by yield increase obtained during the first cut.

The results obtained in field trial indicated that tractor traffic significantly affect physical properties of soil in the $0-30 \mathrm{~cm}$ soil layer. The more intensive wheeling was applied the higher value of bulk density and penetration resistance but lower values of total porosity were recorded. This relation agree with earlier results (Pagliali et al., 2003).
After the first year of experiment the penetration resistance become stable on all treatments and did not change during 2008 and 2009. This effect was confirmed by Bouwman and Arts (2000) where the stabilization was reached after two years. In the second and third year of the experiment a decreases in bulk density and penetration resistance were noticed in the upper, $0-10 \mathrm{~cm}$, soil layer. The main reason for reduction in soil compaction was higher concentration of roots. Approximately $81 \%$ of the root dry matter (RDM) was noticed in the $0-5 \mathrm{~cm}$ layer. It was particularly identified in 2009 when root system was fully developed. This effect can be attributed to perennial plant roots and earthworms activity and is usually account for favourable changes in pore system. Bronick and Lal (2005) in their review indicated that plant roots and their rhizosphere had many favourable effects on soil aggregation. Roots and their exudates are responsible for physical, chemical and biological changes that influence aggregation and soil structure. According to Wuest (2001) in compacted, untilled soil a number of biopores increased with respect to traditional tillage what played favourable role in decreasing soil compaction and root development because they predominately grow in existing biopores. These results were also confirmed by 
Hirth et al. (2005) who described the ability of Lolium perenne L. roots to penetrate biopores in compacted soil.

The roots of smooth-stalked meadow-grass were characterized by high concentration in the upper soil layer (0-5 $\mathrm{cm})$. According to Bengough and Mullins (1990) classification, the roots of Poa pratensis L. belong to root density class described as a 'very dense' $\left(\mathrm{RLD}>20 \mathrm{~cm} \mathrm{~cm}^{-3}\right.$ ).

It has been reported that a common response of the root system to increasing bulk density is a decrease in root length and rooting becoming concentrated in the upper soil layer (Ball-Coello et al., 1998; Lipiec et al., 2003). However, these works concerned mainly annual species. The results obtained in the current experiment with perennial species did not confirm this trend. In the upper soil layer the compaction applied caused the increase in length and dry matter of roots. This positive correlation between soil density and roots characteristics was also confirmed by Ball-Coello et al. (1998). They stated that root length density was positively associated with capillary pore space and aggregation. Increased bulk density can trigger lateral root formation, and in this way contribute to greater root development in the top $10 \mathrm{~cm}$ of compacted soil. Schoonderbeek and Schoute (1994) also found a negative relationship between high macroporosity (pores with diameter $>30 \mu \mathrm{m}$ ) and root length. In soil with greater macroporosity there were fewer roots than in compacted soil. In their study, horizontal cracking caused by wheel traffic compaction resulted in more horizontal root growth. The changes in root morphology described above were attributed to increased moisture conditions and greater soil strength that reduces elongation of root main axes and stimulates branching (Cannell and Hawes, 1994).

In the dry matter production it was observed that tractor traffic decreased plant yields during the second and third harvest. These results are confirmed by those obtained by author (Głąb, 2008) who also noticed the similar yield decline for lucerne. However, in this study the opposite effect was noticed for the first harvest when the traffic treatment increased herbage production. It was probably the result of a long period of time between the first harvests in 2008 and 2009 and the third harvests and trafficking simulations in the previous years. During this time plants recovered from damage caused and regenerated shoots. The increase in yields during the first cut corresponds with results obtained in roots length and dry matter where higher values of the RLD and RDM were recorded in compacted soil. These results indicate that smooth-stalked meadow-grass root found the better growing condition in compacted soil than in a very porous. The results obtained in this study confirm the recent tendency in smooth-stalked meadow-grass utilization. The significance of this species increased as a very important component in mixtures for sport and hard wear. This is ascribed to wear tolerance and capability to recover quickly from the under-ground rhizomes.

\section{CONCLUSIONS}

1. The bulk density and penetration resistance of soil under perennial grass increased with the increase in number of tractor passes.

2. During the three years of smooth-stalked meadowgrass cultivation the soil compaction slightly decreased, especially in the upper soil layer. This effect can be ascribed to the high root concentration.

3. The roots were significantly affected by tractor traffic only in 0-5 cm soil layer. The permanent tractor passes increased the dry matter and length of roots in diameter range of $0.1-0.5 \mathrm{~mm}$.

4. It was noticed that increase in number of passes increased the plants yields in the first cut. During the second and the third cut it was found that multiple passes decreased plant yields. However, the tractor traffic did not result in any changes in smooth-stalked meadow-grass annual yields.

\section{REFERENCES}

Ball-Coelho B.R., Roy R.C., and Swanton C.J., 1998. Tillage alters corn root distribution in coarse-textured soil. Soil Till. Res., 45, 237-249.

Bengough A.G. and Mullins C.E., 1990. Mechanical impedance to root growth: a review of experimental techniques and root growth responses. J. Soil Sci., 41, 341-358.

Bouwman L.A. and Arts W.B.M., 2000. Effects of soil compaction on the relationships between nematodes, grass production and soil physical properties. Appl. Soil Ecol., 14, 3, 213-222.

Bronick C.J. and Lal R., 2005. Soil structure and management: a review. Geoderma, 124, 3-22.

Cannell R.Q. and Hawes J.D., 1994. Trends in tillage practices in relation to sustainable crop production with special reference to temperate climates. Soil Till. Res., 30, 245-282.

Chen G. and Weil R.R., 2010. Penetration of cover crop roots through compacted soils. Plant Soil, 331, 31-43.

Frost J.P., 1998. Effects on crop yields of machinery traffic and soil loosening. Part 1. Effects on grass yield of traffic frequency and date of loosening. J. Agric. Eng. Res., 39, 302-312.

Gajda J., 1997. Floristic composition of meadow in relation to fertilization under conditions of ground water optimal level. Proc. Int. Occasional Symp. EGF, May 19-23, WarszawaŁomża, Poland.

Gląb T., 2005. The influence of roots of perennial legumes on the water retention of soil. Bericht uber die 11 Lysimetertagung, Lysimetrie Im Netzwerk Der Dynamik Von Okosystem, BAL Gumpenstein, Austria, 167-168.

Gląb T., 2008. Effects of tractor wheeling on root morphology and yield of Lucerne (Medicago sativa L.). Grass Forage Sci., 63, 398-406.

Głąb T. and Kopeć S., 2009. Effect of soil compaction on root system morphology and yields of meadow fescue (Festuca pratensis). Polish J. Environ. Studies, 18/2, 219-225.

Hamza M.A. and Anderson W.K., 2005. Soil compaction in cropping systems. A review of the nature, causes and possible solutions. Soil Till. Res., 82, 121-145. 
Hirth J.R., Mckenzie B.M., and Tisdall J.M., 2005. Ability of seedling roots of Lolium perenne L. to penetrate soil from artificial biopores is modified by soil bulk density, biopore angle and biopore relief. Plant Soil, 272, 327-336.

IUSS Working Group WRB, 2007. World Reference Base for Soil Resources. World Soil Resources Reports 103, FAO Press, Rome, Italy.

Kristoffersen A.R. and Riley H., 2005. Effects of soil compaction and moisture regime on the root and shoot growth and phosphorus uptake of barley plants growing on soils with varying phosphorus status. Nutrient Cycling in Agroecosys., 72, 135-146.

Lipiec J., Medvedev V.V., Birkas M., Dumitru E., Lyndina T.E., Rousseva S., and Fulajtar E., 2003. Effect of soil compaction on root growth and crop yield in Central and Eastern Europe. Int. Agrophysics, 17, 61-69.

Milleret R., Le Bayon R.C., Lamy F., Gobat J.M., and Boivin P., 2009. Impact of roots, mycorrhizas and earthworms on soil physical properties as assessed by shrinkage analysis. J. Hydrol., 373, 499-507.

Pagliai M., Marsili A., Servadio P., Vignozzi N., and Pellegrini S., 2003. Changes in some physical properties of a clay soil in
Central Italy following the passage of rubber tracked and wheeled tractors of medium power. Soil Till. Res., 73, 119-129.

Schoonderbeek D. and Schoute J.F.T., 1994. Root and root-soil contact of winter wheat in relation to soil macroporosity. Agric. Ecosys. Environ., 51, 89-98.

Scott D.I., Tams A.R., Berry P.M., and Mooney S.J., 2005. The effects of wheel-induced soil compaction on anchorage strength and resistance to root lodging of winter barley (Hordeum vulgare L.). Soil Till. Res., 82, 147-160.

Smucker A.J.M., Mc Burney S.L., and Srivastova A.K., 1982. Quantitative separation of roots from compacted soil profiles by the hydropneumatic elutriation system. Agron. J., 74, 500-503.

Statistical Yearbook, 2008. Central Statistical Office Press, Warsaw, Poland.

Whalley W.R., Watts C.W., Gregory A.S., Mooney S.J., Clark L.J., and Whitemore A.P., 2008. The effect of soil strength on the yield of wheat. Plant Soil, 306, 237-247.

Wuest S.B., 2001. Soil biopores estimation: effects of tillage, nitrogen and photographic resolution. Soil Till. Res., 62, 111-116. 